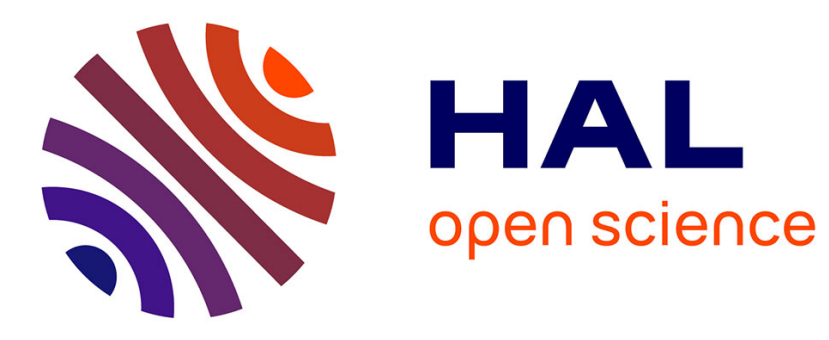

\title{
Denudation of the Côte d'Ivoire-Ghana transform margin from apatite fission tracks.
}

Florence Bigot-Cormier, Christophe Basile, Gérard Poupeau, Jean-Pierre Bouillin, Erika Labrin

\section{- To cite this version:}

Florence Bigot-Cormier, Christophe Basile, Gérard Poupeau, Jean-Pierre Bouillin, Erika Labrin. Denudation of the Côte d'Ivoire-Ghana transform margin from apatite fission tracks.. Terra Nova, 2005, 17(2), pp.189-195. 10.1111/j.1365-3121.2005.00605.x . hal-00096370

\section{HAL Id: hal-00096370 \\ https://hal.science/hal-00096370}

Submitted on 26 Sep 2006

HAL is a multi-disciplinary open access archive for the deposit and dissemination of scientific research documents, whether they are published or not. The documents may come from teaching and research institutions in France or abroad, or from public or private research centers.
L'archive ouverte pluridisciplinaire HAL, est destinée au dépôt et à la diffusion de documents scientifiques de niveau recherche, publiés ou non, émanant des établissements d'enseignement et de recherche français ou étrangers, des laboratoires publics ou privés. 


\section{Denudation of the Côte d'Ivoire-Ghana transform continental margin from apatite fission tracks}

*Florence Bigot-Cormier, ${ }^{* *}$ Christophe Basile, ${ }^{* * *}$ Gérard Poupeau,

**Jean-Pierre Bouillin and **Erika Labrin

*Géosciences Azur, UMR 6526, Faculté des Sciences, Parc Valrose, 06108 Nice cedex 02, France. Florence.Bigot@unice.fr.

**LGCA, CNRS-UMR 5025, OSUG, Université Joseph Fourier, Grenoble, France. cbasile@ujf-grenoble.fr; bouillin@ujf-grenoble.fr ; erika.labrin@ujf-grenoble.fr.

*** CRPAA-Maison de l'Archéologie, UMR 5060 of CNRS, Université Bordeaux III, 33607 Pessac, France. gerard.poupeau@montaigne.ubordeaux.fr.

\section{ABSTRACT}

Apatite fission track analysis of samples from the shoulder (marginal ridge) of the Côte d'Ivoire-Ghana transform continental margin reveal a cooling of the margin between 85 and $65 \mathrm{Ma}$ for the central and eastern parts of the ridge. All samples were heated in situ during sedimentary burial with a temperature $>120^{\circ} \mathrm{C}$, except for two samples located in the eastern part which were heated between $105-120^{\circ} \mathrm{C}$. For the first time, age/depth diagram along a transform margin shows a shape involving erosion starting at the bottom of the continental slope, then stepping backwards towards the edge of the slope. This retrogressive erosion can result from the deepening of the lithospheric plate sliding along the transform margin, from thick continental crust to thin continental crust, and finally to oceanic crust. This process could be at the origin of the shoulder uplift by flexural response to the important crustal discharge $(>2 \mathrm{~km})$.

Keywords: Equatorial Atlantic, transform faults, fission-track dating, denudation

\section{INTRODUCTION AND GEOLOGICAL SETTING}

North of the Gulf of Guinea, the Côte d'Ivoire-Ghana (CIG) ridge is $25 \mathrm{~km}$-width (Figure 1), $130 \mathrm{~km}$-long structure, that strikes WSW-ENE from the Romanche Fracture Zone to the Ghanaian shelf (Figure 2A). It represents the southern edge of the Deep Ivorian Basin (DIB). The bathymetric ridge overlays a strongly asymmetric structural ridge, standing above the DIB by about $1300 \mathrm{~m}$, while its southern slope dominates the ocean floor by a $>4000 \mathrm{~m}$ scarp (Figure 1) (Basile et al., 1993).

According to Mascle and Blarez (1987) and Basile et al. (1993, 1998), three stages can be distinguished in the tectonic evolution of the CIG transform margin:

- Early Cretaceous (Aptian or older) intracontinental rifting and transform faulting. The rifting ends with the formation of an oceanic crust west of the DIB during Albian-Cenomanian times (105-95 Ma). During this first stage, lacustrine sedimentation began in half-grabens delimited by N-S and NE-SW normal faults, and was overlaid by marine sediments prograding from the south, suggesting that the sediments came from the Brazilian shelf (Blarez and Mascle, 1988, Lamarche et al., 1997). These deformed sediments outcrop all along the southern slope of the CIG marginal ridge, and lie below an unconformity along the northern slope (Figure 1). Biostratigraphy did not provide ages younger than late Albian in this sedimentary unit.

- Turonian continent-ocean active transform margin, resulting from the equatorial Atlantic onset of seafloor spreading about 90 Ma ago (Mascle et al., 1988). Contemporaneous sediments are known only in the Deep Ivorian Basin, and onlap the northern slope of the marginal ridge (Figure 1). 
- After the passing of the oceanic accretion axis south of the transform margin during the Santonian (85-80 Ma), the continent-ocean transform margin was passive. Younger sediments filled horizontally the Deep Ivorian Basin (Figure 1). The present day continental slope exhibits three distinct morphostructural units (Basile et al., 1993; Lamarche et al., 1997; Sage et al., 1997, 2000) (Figure 2A): (i) the central part (very steep and about linear continental slope) that coincides with the topographically high CIG ridge; (ii) the westernmost part (ridge termination) where the continental slope becomes less steep and changes from ENE-WSW to E-W strike; (iii) the easternmost part, which belongs to the ghanaian continental slope, that does not exhibit any marginal ridge, and where canyons cutting the slope are fed directly from the ghanaian shelf.

Since Todd and Keen (1989), the formation of transform marginal ridges has often been explained by heating (and associated uplift) of the continental lithosphere by the accretion of oceanic crust against the transform margin. More recently, based on numerical modelisation and apatite fission tracks (FT) data from ODP (Oceanic Drilling Program) Leg 159 samples, Clift and Lorenzo (1999) explained the uplift by a combination of thermal uplift and tectonic denudation associated to transtensional faulting. Nevertheless, as the CIG ridge appeared as an uplifted area since the late Albian (Basile et al., 1998), a long time before the oceanic accretion against the transform margin, this thermal model does not seem suitable.

Along the CIG ridge, thermal aspects of the evolution of the transform marginal ridge were first investigated through apatite FT in six samples from the Equanaute cruise (Bouillin et al., 1994, 1997, 1998) and additional samples from ODP Leg 159 (Clift et al., 1998; Bouillin et al., 1998), which provided only one vertical section and sparse informations along the margin. While the ODP core samples came from drill holes atop or near to the top of the CIG ridge, 153 Equanaute samples were taken in situ along fourteen submarine profiles, dedicated to the sedimentary, stratigraphic and structural study of the $2.5 \mathrm{~km}$ high outcrops along the steep continental slope (Mascle et al., 1998). We integrate in this study the six previously published apatite FT analysis and eleven additional samples to investigate and quantify for the first time the spatial (i.e. both horizontaly and through several vertical sections) and temporal evolution of heating and denudation along the uplifted shoulder of the transform continental margin. We first discuss the thermal history, then the vertical motion of the CIG ridge in relation with the crossing of the oceanic accretion axis.

\section{SAMPLING STRATEGY AND EXPERIMENTAL PROCEDURES}

The seventeen analysed Equanaute samples come from the Lower Cretaceous formation (middle to latest Albian: Klingebiel, 1976; Mascle et al., 1998) between 4800 and $2200 \mathrm{~m}$-depth, all along the marginal ridge, and as far as possible at various depths along the same diving profiles (EN02, EN04, EN07, EN08) (Figure 2 and table 1).

Apatite FT datations were realised with the external detector method (Hurford and Green, 1983; Hurford and Carter, 1991) using the zeta technique (Fleischer and Hart, 1972).

Irradiations were performed in the Orphée nuclear reactor of the Centre d'Etudes Nucléaires of Saclay (France). Each age was calculated with the central age method (Galbraith and Laslett, 1993), except for the previously studied samples (Bouillin et al., 1997) (pooled ages; Galbraith, 1981; Green, 1981).

Confined track lengths were measured in 13 apatite samples, including six previously studied by Bouillin et al. (1997).

\section{NEW RESULTS}

Analytical data are presented in Table 1 and sample locations and their FT ages in Figure 2. In all samples except the two easternmost ones, there is only one age population among the crystals dated, as suggested by the $\chi^{2}$ test of Galbraith (1981) and Green (1981) and by the standard deviation obtained for central ages (Galbraith and Laslett, 1993). The corresponding confined track lengths are consistently longer than $14 \mu \mathrm{m}$ with standard deviation from 1.1 (EN09-9) to $1.5 \mu \mathrm{m}$ (EN07-11) (Table 1), which testify that the CIG margin cooled rapidly. Figure 2B gives two typical examples of radial plots for samples of this group. These ages range from 92 to $64 \mathrm{Ma}$, and are all younger than the stratigraphic age of the sediments. There is no clear trend of ages horizontally 
along the transform margin (Figure 2A); vertically it appears that the older ages come from the deeper samples, while the younger ages come from the shallower samples.

In the easternmost samples EN02-7 and EN02-8, $\chi^{2}$ probabilities $<5 \%$ indicate that more than one age population is present among the dated apatites (Table 1). In sample EN02-7, the Galbraith (1981) method discriminates two age populations, aged respectively 85.4 \pm 7.3 and $147.4 \pm 14.9 \mathrm{Ma}$ (Figure $2 \mathrm{~B}$ ). In EN02-8, dated with the same number of apatite as EN02-7, the large dispersion of individual grains FT ages do not allow one to identify age populations.

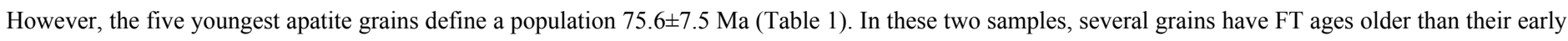
Cretaceous sedimentation age (Mascle et al., 1996), hence they were not heated enough in situ to lose their pre-detrital tracks. The individual grains age distributions in these two samples and confined track lengths in EN02-07 suggest that (i) this part of the CIG was only middly affected by post-depositional heating and that (ii) apatites with various chemical compositions, hence various thermal sensitivity to track annealing, are present. Electron microprobe analyses performed on five ODP samples from the central part of the CIG ridge show that fluorapatites (losing tracks at about $105^{\circ} \mathrm{C}$ ) are predominant over chlorapatites (losing tracks at about $\left.120^{\circ} \mathrm{C}\right)$ (Green et al., 1987). The distribution of individual grains FT ages in samples EN02-7 and EN02-8 might be a consequence of such a mixing.

\section{DISCUSSION AND CONCLUSION}

\section{- Heating -}

Most apatites from ODP Sites 959 and 960 belongs to a siliciclastic sedimentary unit, respectively early Albian (105 Ma) and late Turonian (90 Ma) in age, overlying an erosional unconformity. For these samples with central ages in the range from 90 to 110 Ma and mean confined track lengths 12.4 to 13.7 $\mu \mathrm{m}$, modelling of fission track lengths suggests a first recording of tracks at about 110-115 Ma, that means before the deposition (Bouillin et al., 1998; Clift et al., 1998). So, the post-unconformity sediments were not heated above $60^{\circ} \mathrm{C}$ (Holmes, 1998; Wagner and Pletsch, 2001 ). Only one ODP sample retrieved from below the unconformity at Site 959 shows a single population central age of $88 \pm 4$ Ma (Clift et al., 1998) indicating that all their FT were lost in situ by heating after their sedimentation. Similarly, detrital apatites sampled along the southern continental slope were heated after their sedimentation, and FT were lost either partially for samples EN02-7 and EN02-8, or completely for all other samples. So in situ heating of apatites reached more than $120^{\circ} \mathrm{C}$ below the unconformity and all along the southern slope, except in the eastern part where the maximum temperatures reached were between $\sim 105^{\circ} \mathrm{C}$ and $120^{\circ} \mathrm{C}$ at sites EN02-7 and EN02-8.

Heating associated to the Santonian (85-80 Ma) oceanic accretion axis can not be responsible to the older in situ heating at the western end of the ridge ( $>$ $90 \mathrm{Ma}$, samples EN9-2 and EN9-4) (Figure 2A). Nevertheless, this heating mechanism cannot be excluded for the younger samples. We suggest as an alternative mechanism that heating was associated to sedimentary burial, probably with an high geothermal gradient (present-day gradient $48^{\circ} \mathrm{C} / \mathrm{km}$ at $\mathrm{ODP}$ Site 959; Mascle et al., 1996) during deposition of the very thick Aptian-Albian sedimentary unit in intracontinental transform basins (Basile et al., 1998).

\section{- Cooling and denudation -}

All samples with a single grain age population $\left(\mathrm{P}\left(\chi^{2}\right)>5 \%\right)$ are represented in the age/depth diagram of Figure 3 . There is a clear age/depth correlation, with the older ages systematically at the bottom of the continental slope, and the younger ages at the top, unlike what is commonly observed in continental areas. Moreover, clear-cut correlations appear in each of the three morphostructural units (western, central and eastern) of the continental slope. In each area, denudation and cooling started in the vicinity of the continental slope bottom and reached its top (two kilometers higher) ten million years latter. This striking result can be explained by retrogressive erosion of the continental slope: if the bottom of the continental slope was fixed while its steepness decreased with time, the cooling of samples distributed across today's slope occurred later at the top than at the bottom (sections in Figure 4). 
In this retrogressive mechanism, the FT ages from the sediments overlying the unconformity on the northern slope of the ridge (90-110 Ma, see Bouillin et al., 1998 and Clift et al., 1998) result from previously cooled apatites, all older than the erosion phase recorded by the unconformity, eroded near the crest of the marginal ridge and transported along the northern slope (Figure 4). On the contrary, the apatites on the southern slope are cooled in situ as soon as there are close enough to the surface, since the formation of the continental slope at the very bottom (now covered by a thick sedimentary pile), and more and more recently towards the crest of the ridge as soon as the continental slope steps backwards, probably by gravity sliding on a very steep slope (Figure 4). Before the oceanic accretion against the transform margin, the sediments produced by the erosion of the continental slope were transported on the oceanic crust, and now lie in the Romanche Fracture Zone several thousand kilometers west of the CIG margin (Honnorez et al., 1993; Bonatti et al., 1996). After the oceanic accretion, erosion of the continental slope resulted in very thick sedimentary units (more than $2 \mathrm{~km}$, Figure 1) overlying the new crust.

To explain previously published cooling ages, Clift and Lorenzo (1999) proposed a transtensional tectonic unloading this margin. Nevertheless, there is not very clear structural argument neither in seismic data nor in the scarp to support this hypothesis. Moreover, denudation by a transtensional fault located along the continental slope may produce older FT ages at the top of the slope than at the bottom. The new set of FT data presented in this paper clearly discard Clift and Lorenzo (1999) hypothesis, and makes the proposed retrogressive erosion much more reasonable.

Seismic sections show that the base of the continental slope is between 6 and $7 \mathrm{~km}$-deep (Figure 1) (Sage et al., 1997). An extrapolation of the age/depth correlation to such depths indicates that denudation might have started about $90 \mathrm{Ma}$ ago in the eastern and central parts of the continental slope, and >100 Ma ago in the western part (Figure 3). These ages are consistent with the formation of a late Albian deep basin west of the marginal ridge (ODP Site 962, Basile et al., 1998), and with a deep transform valley bounding the continental slope during the Turonian continent-ocean active transform stage (Figure 4). Consequently, the overall thermal history/denudation of this margin seems to be associated to this active transform stage, and not as previously expected to the passing of the oceanic accretion axis. In all areas, cooling at the top of the continental slope seems to be contemporaneous and younger than 80 Ma, with the partial exception of the easternmost samples that where not buried enough to erase the previous FT.

Finally, the retrogressive erosion which affected the marginal ridge produced an important lithospheric discharge, that increased both with the deepening of the crust sliding against the transform margin (from thick continental crust to thin continental crust, and finally to oceanic crust, Figure 4) and with the retrogressive erosion, and that might have initiated the flexural uplift of the CIG ridge (Basile and Allemand, 2002).

\section{ACKNOWLEDGEMENT}

We wish to thank the Equanaute crew and more specially J. Mascle, M. Guiraud, J. Benkhelil, G. Mascle and M. Cousin, scientists who sampled the CIG ridge from the Nautile. We also thank three anonymous reviewers for their fruitfull comments.

\section{REFERENCES}

Basile, C., and Allemand, P., 2002. Erosion and flexural uplift along transform faults: Geophysical Journal International, v. 151, p. 646-653.

Basile, C., Mascle, J., Popoff, M., Bouillin, J.-P., and Mascle, G., 1993, The Côte d'Ivoire-Ghana transform margin: a marginal ridge structure deduced from seismic data: Tectonophysics, v. 222, p. 1-19.

Basile, C., Mascle, J., Benkhelil, J., and Bouillin, J.-P., 1998, Geodynamic evolution of the Cote d'Ivoire-Ghana transform margin; an overview of Leg 159 results: Proceedings of the Ocean Drilling Program, Scientific Results, v. 159, p. 101-110.

Blarez, E., and Mascle, J., 1988, Shallow structure and evolution of the ivory coast and Ghana transform margin: Marine Petroleum geology, v. 5, p. 54-64. Bonatti, E., Ligi, M., Borsetti, A.M., Gasperini, L., Negri, A., Sartori, R., 1996, Lower Cretaceous deposits trapped near the equatorial Mid-Atlantic Ridge: Nature, v. 380, 6574, p. 518-520. 
Bouillin, J.P., Poupeau, G., Riou, L., Sabil, E., Basile, C., Mascle, J., Mascle, G., and the Equanaute Group, 1994, La marge transformante de Côte d'IvoireGhana: premières données thermochronologiques (campagne Equanaute, 1992): Compte Rendu de.l'Académie des Sciences de Paris, v. 318, p. 13651370.

Bouillin, J.-P., Poupeau, G., Labrin, E., Basile, C., Sabil, N., Mascle, J., Mascle, G., Guillot, F., and Riou, L., 1997, Fission track study: heating and denudation of marginal ridge of the Ivory Coast-Ghana transform margin: Geo-Marine letters, v. 17, p. 55-61.

Bouillin, J.-P., Poupeau, G., Basile, C., Labrin, E., and Mascle, J., 1998, Thermal constraints on the Côte d'Ivoire-Ghana transform margin: evidence from apatite fission tracks: Proceedings of the Ocean Drilling Program, Scientific Results, v. 159, p. 43-48.

Clift, P.D., Carter, A., Hurford, A. J., and Bouillin, J.-P., 1998, Apatite fission track dating of ODP sites 959 and 960 on the transform continental margin of Ghana, west Africa: Proceedings of the Ocean Drilling Program, Scientific Results,v. 159.

Clift, P.D. and Lorenzo, J.M., 1999, Flexural unloading and uplift along the Côte d'Ivoire-Ghana transform margin, equatorial Atlantic. Journal of Geophysical Research, v. 104, B11, p. 25257-25274.

Dunkl, I., 2001, The additional parameters - a short introduction to the data handling with TRACKKEY 4.1: OnTrack, v. 11, p. 19-22.

Dunkl, I., 2002, TRACKKEY: a Windows program for calculation and graphical presentation of fission track data: Computers \& Geosciences, v. 28 (2), p. $3-$ 12.

Fleischer, R.L., Hart, H.R., Jr., 1972, Fission track dating: techniques and problems, in Bishop, W.W., Miller, J.A., Cole, S., eds., Calibration of Hominoid Evolution: Scottish Academic press, Edinburg, p. 135-170.

Galbraith, R., 1981, On stastitical models for fission track counts: Mathematical Geology, v. 13, p. 471-488.

Galbraith, R.F., and Laslett, G.M., 1993, Statistical models for mixed fission track ages: Nuclear tracks Radiation Measurement, v. 21, p. 459-470.

Green, P.F., 1981, A new look at stastistics in fission tracks dating: Nuclear Tracks, v. 5, p. 76-86.

Green, P.F., Duddy, I.R., Gleadow, A.J.W., and Lovering, J.F., 1987, Apatite fission track analysis as a paleotemperature indicator for hydrocarbon exploration, ed., Neaser N.D.: Springer Verlag, v. 1-2.

Holmes, M.A., 1998, Thermal diagenesis of Cretaceous sediment recovered at the Côte d'Ivoire-Ghana transform margin, in Mascle, J., Lohmann, G.P., Clift, P.D., eds., Proceedings of the Ocean Drilling Program, Scientific Results, v. 159, p. 53-70.

Honnorez, J., Villeneuve, M., Mascle, J., 1993: Old Continent-Derived Metasedimentary Rocks in the Equatorial Atlantic - An Acoustic Basement Outcrop Along the Fossil Trace of the Romanche Transform Fault at 6 degrees 30'W, Marine Geology, v. 117, 1-4, p. $237-251$.

Hurford, A.J., and Carter, A.J.W., 1991, The role of fission track dating in discrimination of provenance, in Morton, A.C., and Todd, S.P., eds., Developments in Sedimentary Provenance Studies, PDW Haughton: Geological Society of London Special Publication, v. 57, p. 67-78.

Hurford, A.J., and Green, P.F., 1983, The zeta calibration of fission track dating: Isotope Geoscience, v. 1, p. 285-317.

Klingebiel, A., 1976, Sediments et milieux sedimentaires dans le golfe de Benin: Bulletin du Centre de Recherche Exploration.-Production. Elf Aquitaine, v. 1, p. 129-148.

Lamarche, G., Basile, C., Mascle, J., and Sage F., 1997, The Côte d'Ivoire - Ghana transform margin: sedimentary and tectonic structure from MCS data: Geo-marine Letters, v. 17 (1), p. 62-69.

Mascle, J., and Basile, C., 1998, Marges continentales transformantes: Comptes Rendus Académie des Sciences, Paris, v.326, p. 827-838.

Mascle, J., and Blarez, E., 1987, Evidence for transform margin evolution from the Ivory Coast-Ghana continental margin: Nature, v. 326, p. 378-381.

Mascle, J., Blarez, E., and Marinho, M., 1988, The shallow structure of the Guinea and Côte d'Ivoire-Ghana transform margins: their bearing on the equatorial atlantic mesozoic evolution: Tectonophysics, v. 155, p. 193-209.

Mascle, J., Lohmann, G.P., Clift, P.D., and shipboard scientific party, 1996: Proceedings of the Ocean Drilling Program, Initial reports, v. 159, 616 p. 
Mascle, J., Guiraud, M., Benkhelil, J., Basile, C., Bouillin, J.-P., Mascle, G., Cousin, M., Durand, M., Dejax, J., and Moullade, M., 1998, A geological field trip to the Côte d'Ivoire-Ghana transform margin: Oceanologica Acta, v. 21, p. 1-20.

Sage, F., Pontoise, B., Mascle, J., Basile, C., and Arnould, L., 1997, Crustal structure and ocean-continent transition at marginal ridge: the Côte d'IvoireGhana marginal ridge: Geo-Marine Letters, v. 17, p. 40-48.

Sage, F., Basile, Ch., Mascle, J., Pontoise, B., and Whitmarsh R.B., 2000, Crustal structure of the continent-ocean transition off the Côte d'Ivoire-Ghana transform margin: implications for thermal exchanges across the palaeotransform boundary: Geophysical Journal International, v. 143, p. 662-678.

Todd, B.J., and Keen, C.E., 1989, Temperature effects and their geological consequences at transform margins: Canadian Journal of Earth Sciences., v. 26, p. 2591-2603.

Wagner, T., and Pletsch, T., 2001, No major thermal event on the mid-Cretaceous Côte d'Ivoire-Ghana transform margin: Terra Nova, v. 13, p. 165-171.

Figure 1- N-S section of the CIG transform continental margin with main sedimentary reflectors (vertical exageration 10, modified from Mascle and Basile, 1998), and stratigraphic relationships between three sections across the transform margin (ODP Sites 959 and 960 (modified from Mascle et al., 1996), and Equanaute dives (Mascle et al., 1998)).

Figure 2- Bathymetry (in $\mathrm{m}$ ) and fission track ages of the CIG transform margin. 2A: samples from diving and ODP Sites located on a bathymetric map. Insert: main morphostructural features of the CIG margin and location of -A (V indicates the continent-ocean boundary; the CIG ridge is shaded). Main map: black triangles, circles and squares refer to eastern, central and western areas, respectively (see text) with $\mathrm{P}\left(\chi^{2}\right)>5 \%$. Samples dated in this study are in bold, samples from Bouillin et al. (1997) in italic, samples from ODP (studied by Bouillin et al., 1998 and Clift et al., 1998) underlined. The asterisks indicate weighted ages. $\mathrm{P}\left(\chi^{2}\right)$ computed following Green (1981). 2B: Radial plots (age precision for each counted apatite grain) and confined fossil fission track length distribution in CIG samples from three different zones. Lc, sd, n: average length of confined fossil tracks measured, standard deviation and number of tracks, respectively.

Figure 3- Age/depth diagram. Same symbols as figure 2A.

Figure 4- Evolution of the CIG margin (modified from Basile et al., 1998) with location of ODP Sites 959 to 962 (black dots when below sea level, grey dots above sea level). Sediments overlying the continental unconformity surface (from Late Albian stage to present-day) and the oceanic crust are not shown. Approximate scales $110 \mathrm{~km}$ horizontaly along transform fault, and $7 \mathrm{~km}$ vertically between the top of the marginal ridge and the adjacent oceanic crust (Campanian stage). To the right, zoom on the marginal ridge (without vertical exageration) with the expected position of the continental slope at $90,80,65$ Ma and present day (0). See text for comments. Black stars, samples hotter than $120^{\circ} \mathrm{C}$; gray stars, samples cooling from 120 to $60^{\circ} \mathrm{C}$; white stars, samples previously cooled; banded section represents the part of the continental slope eroded from the previous stage; large arrows indicate the erosion of the marginal ridge and transport of detrital sediments. Bold lines indicate active faults. 
Table 1. Fission track analytical data

\begin{tabular}{|c|c|c|c|c|c|c|c|c|c|c|c|c|c|c|c|}
\hline \multirow[t]{2}{*}{$\underset{\text { W } \rightarrow \text { E }}{\text { Sample }}$} & \multirow[t]{2}{*}{$\underset{\text { m }}{\text { Depth }}$} & \multirow[t]{2}{*}{$\mathbf{n}$} & \multirow[t]{2}{*}{$\begin{array}{c}\text { Df } \\
10^{5} / \mathrm{cm}^{2}\end{array}$} & \multirow[t]{2}{*}{$\mathbf{N f}_{\mathrm{f}}$} & \multirow[t]{2}{*}{$\begin{array}{c}\mathrm{Di} \\
10^{5} / \mathrm{cm}^{2}\end{array}$} & \multirow[t]{2}{*}{$\mathbf{N i}_{\mathbf{i}}$} & \multirow[t]{2}{*}{$\underset{10^{5} / \mathrm{cm}^{2}}{\mathrm{Dm}}$} & \multirow[t]{2}{*}{$\mathbf{N m}$} & \multicolumn{2}{|c|}{$\frac{\text { Dispersion }}{(\%)}$} & \multirow[t]{2}{*}{$\zeta$} & \multirow[t]{2}{*}{$\begin{array}{c}\mathbf{t} \pm 1 \sigma \\
\mathrm{Ma}\end{array}$} & \multirow[t]{2}{*}{$\begin{array}{l}\mathbf{L c} \\
\mu \mathrm{m}\end{array}$} & \multirow[t]{2}{*}{$\begin{array}{c}\text { st. dev. } \\
\mu \mathrm{m}\end{array}$} & \multirow[t]{2}{*}{ nc } \\
\hline & & & & & & & & & $\mathbf{P}\left(\chi^{2}\right)$ & S.E. & & & & & \\
\hline En 01-3 & -3479 & $\begin{array}{l}14 \\
10\end{array}$ & $\begin{array}{l}12.5 \\
8.63\end{array}$ & $\begin{array}{c}(1275) \\
(286)\end{array}$ & $\begin{array}{l}13.4 \\
9.15\end{array}$ & $\begin{array}{c}(1363) \\
(303)\end{array}$ & $\begin{array}{l}5.302 \\
5.302\end{array}$ & $\begin{array}{l}(17910) \\
(17910)\end{array}$ & $\begin{array}{l}>99 \\
>99\end{array}$ & - & $\begin{array}{l}339 \pm 7 \\
321 \pm 4\end{array}$ & $\begin{array}{c}84 \pm 8^{2} \\
80 \pm 13^{5} \\
83.0 \pm 3.5^{*}\end{array}$ & 14.58 & 1.22 & 52 \\
\hline En 02-8 & $\begin{array}{l}-2800 \\
\text { You } \\
\text { ng }\end{array}$ & $\begin{array}{c}18 \\
5\end{array}$ & 16.29 & (1124) & 7.13 & (492) & 3.369 & $(9090)$ & $\begin{array}{c}\mathrm{R} \\
96.9\end{array}$ & $\begin{array}{c}\mathrm{R} \\
<1\end{array}$ & $297 \pm 17$ & $\begin{array}{c}125.3 \pm 10.6^{1} \\
75.6 \pm 8.7\end{array}$ & ------ & ------ & -- \\
\hline En 02-7 & $\begin{array}{l}-2900 \\
\text { pop. } 1 \\
\text { pop. } 2\end{array}$ & $\begin{array}{c}18 \\
12 \\
6\end{array}$ & $\begin{array}{l}12.63 \\
2.58 \\
4.31\end{array}$ & $\begin{array}{c}(1283) \\
(699) \\
(584)\end{array}$ & $\begin{array}{l}5.94 \\
1.50 \\
1.45\end{array}$ & $\begin{array}{l}(603) \\
(407) \\
(196)\end{array}$ & $\begin{array}{l}3.369 \\
3.369 \\
3.369\end{array}$ & $\begin{array}{l}(9090) \\
(9090) \\
(9090)\end{array}$ & $\begin{array}{c}<1 \\
94.9 \\
74.7\end{array}$ & $\begin{array}{c}21.39 \\
<1 \\
<1\end{array}$ & $297 \pm 17$ & $\begin{array}{c}103.7 \pm 6.9^{1} \\
\mathbf{8 5 . 4} \pm 7.3 \\
\mathbf{1 4 7 . 4} \pm \mathbf{1 4 . 9}\end{array}$ & 12.50 & 1.80 & 70 \\
\hline En 04-5 & -2600 & 13 & 6.72 & (597) & 4.57 & $(406)$ & 3.369 & (9090) & 22.6 & 13 & $297 \pm 17$ & $73.5 \pm 7.0^{1}$ & ------ & ------ & -- \\
\hline En 04-9 & -2405 & $\begin{array}{l}17 \\
10\end{array}$ & $\begin{array}{l}4.10 \\
4.50\end{array}$ & $\begin{array}{l}(486) \\
(149)\end{array}$ & $\begin{array}{l}3.71 \\
4.14\end{array}$ & $\begin{array}{l}(440) \\
(137)\end{array}$ & $\begin{array}{c}3.793 \\
3.79\end{array}$ & $\begin{array}{l}(5017) \\
(5017)\end{array}$ & $\begin{array}{l}53.4 \\
>99\end{array}$ & - & $\begin{array}{l}339 \pm 7 \\
321 \pm 4\end{array}$ & 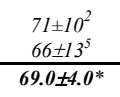 & 15.21 & 1.22 & 20 \\
\hline En 04-10 & -2200 & 26 & 8.51 & (1138) & 6.60 & $(882)$ & 3.369 & (9090) & 94.6 & $<1$ & $297 \pm 17$ & $64.2 \pm 4.7^{1}$ & 14.39 & 1.26 & 99 \\
\hline En 06-5 & -3465 & $\begin{array}{c}8 \\
25\end{array}$ & $\begin{array}{l}6.38 \\
5.00\end{array}$ & $\begin{array}{l}(355) \\
(387)\end{array}$ & $\begin{array}{l}5.99 \\
4.82\end{array}$ & $\begin{array}{l}(333) \\
(373)\end{array}$ & $\begin{array}{l}3.865 \\
3.865\end{array}$ & $\begin{array}{l}(10223) \\
(10223)\end{array}$ & $\begin{array}{l}>99 \\
>99\end{array}$ & - & $\begin{array}{c}339 \pm 7 \\
322 \pm 25\end{array}$ & $\begin{array}{c}70 \pm 11^{2} \\
65 \pm 14^{4} \\
68.0 \pm 4.5^{*}\end{array}$ & 14.44 & 1.21 & 45 \\
\hline En 06-8 & -3300 & 33 & 8.63 & (2024) & 7.39 & (1735) & 3.748 & (17350) & 97,3 & $<1$ & $330 \pm 7$ & $71.8 \pm 2.9^{1}$ & 14.68 & 1.37 & 89 \\
\hline En 07-1 & -4300 & 30 & 7.16 & (1040) & 5.98 & (868) & 3.862 & (12259) & $>99$ & $<1$ & $330 \pm 7$ & $75,9 \pm 3.9^{1}$ & ------- & ------- & -- \\
\hline En 07-11 & -3600 & 25 & 11.43 & (1273) & 9.27 & (1033) & 3.748 & (17350) & 20,0 & 14 & $330 \pm 7$ & $73.4 \pm 4.2^{1}$ & 14.21 & 1.49 & 113 \\
\hline En 08-2 & -4400 & 30 & 8.98 & (1137) & 7.10 & (899) & 3.748 & $(17350)$ & $>99$ & $<1$ & $330 \pm 7$ & $77.8 \pm 3.9^{1}$ & 14.00 & 1.40 & 97 \\
\hline En 08-6 & -3700 & 24 & 6.10 & (775) & 4.72 & (599) & 3.748 & $(17350)$ & $>99$ & $<1$ & $330 \pm 7$ & $79.6 \pm 4.7^{1}$ & 14.72 & 1.16 & 105 \\
\hline En 09-2 & -3905 & $\begin{array}{c}22 \\
5\end{array}$ & $\begin{array}{c}10.01 \\
6.59\end{array}$ & $\begin{array}{c}(1785) \\
(218)\end{array}$ & $\begin{array}{l}7.21 \\
5.05\end{array}$ & $\begin{array}{c}(1287) \\
(167)\end{array}$ & $\begin{array}{l}3.793 \\
5.302\end{array}$ & $\begin{array}{l}(5017) \\
(17910)\end{array}$ & $\begin{array}{c}87 \\
85.25\end{array}$ & - & $\begin{array}{l}339 \pm 7 \\
339 \pm 7\end{array}$ & $\begin{array}{c}89 \pm 8^{2} \\
117 \pm 24^{2} \\
\mathbf{9 2 . 0} \pm 3.5^{*}\end{array}$ & 15.16 & 1.13 & 65 \\
\hline En 09-4 & -3524 & $\begin{array}{l}18 \\
14\end{array}$ & $\begin{array}{l}12.4 \\
9.67\end{array}$ & $\begin{array}{c}(1231) \\
(902)\end{array}$ & $\begin{array}{l}8.71 \\
7.22\end{array}$ & $\begin{array}{l}(861) \\
(673)\end{array}$ & $\begin{array}{l}3.793 \\
3.793\end{array}$ & $\begin{array}{l}(5017) \\
(10223)\end{array}$ & $\begin{array}{l}>99 \\
>99\end{array}$ & - & $\begin{array}{l}339 \pm 7 \\
339 \pm 7\end{array}$ & $\begin{array}{c}92 \pm 9^{2} \\
88 \pm 10^{2} \\
\mathbf{9 0 . 0} \pm 3 . \mathbf{5}^{*}\end{array}$ & 14.82 & 1.15 & 74 \\
\hline En 09-9 & -2675 & 12 & 6.11 & (374) & 5.10 & (312) & 3.865 & (10223) & $>99$ & - & $339 \pm 7$ & $78.0 \pm 6.0^{2}$ & 14.24 & 1.12 & 16 \\
\hline En 11-5 & -4800 & 5 & 5.59 & (213) & 4.02 & (153) & 3.862 & (12259) & 98.0 & $<1$ & $330 \pm 7$ & $85.7 \pm 9.3^{1}$ & ----- & ------ & -- \\
\hline En 12-5 & -3300 & $\begin{array}{l}15 \\
11\end{array}$ & $\begin{array}{l}7.32 \\
7.10\end{array}$ & $\begin{array}{l}(904) \\
(733)\end{array}$ & $\begin{array}{l}6.11 \\
5.85\end{array}$ & $\begin{array}{l}(755) \\
(604)\end{array}$ & $\begin{array}{l}3.748 \\
3.748\end{array}$ & $\begin{array}{l}(17350) \\
(17350)\end{array}$ & $\begin{array}{l}90.2 \\
>99\end{array}$ & $\begin{array}{l}<1 \\
<1\end{array}$ & $\begin{array}{l}330 \pm 7 \\
316 \pm 7\end{array}$ & $\begin{array}{l}73.7 \pm 4.0^{1} \\
71.5 \pm 4.3^{3} \\
\mathbf{7 2 . 7} \pm \mathbf{2 . 9}\end{array}$ & 14.22 & 1.29 & 105 \\
\hline
\end{tabular}

Note: Total number of tracks and track density in kapton external detectors associated with neutron glass wafer monitors NIST 962 or CN5. Each observer have a zeta $(\zeta)$ calibration factor (Fleischer and Hart, 1972):

1- Florence Bigot-Cormier, 2- Erika Labrin, 3- Ali Azdimousa, 4- Florence Gillot 5- Naima Sabil.

Datations by 2 (for a part), 4, 5 from Bouillin et al. (1997).

* Weighted values; n, number of crystal dated; Df, Di, Dm, spontaneous, induced and monitor track densities, respectively; Nf, $\mathrm{Ni}, \mathrm{Nm}$, spontaneous, induced and monitor track counted, respectively; Lc, st. Dev., nc: confined tracks, standard deviation and number of confined tracks measured.

$\mathrm{P}\left(\chi^{2}\right)$ is the probability of $\chi^{2}$ for $\mathrm{n}$ degrees of freedom where $\mathrm{n}=$ number of crystals dated -1 (Galbraith, 1981; Green, 1981); $\mathrm{R}$, refused test; Italic characters are pooled statistics ages (Bouillin et al., 1997) following Galbraith (1981) and Green (1981); Normal characters are central ages calculated with their standard erreur (S.E.) (Galbraith and Laslett, 1993; Dunk1, 2001, 2002). 


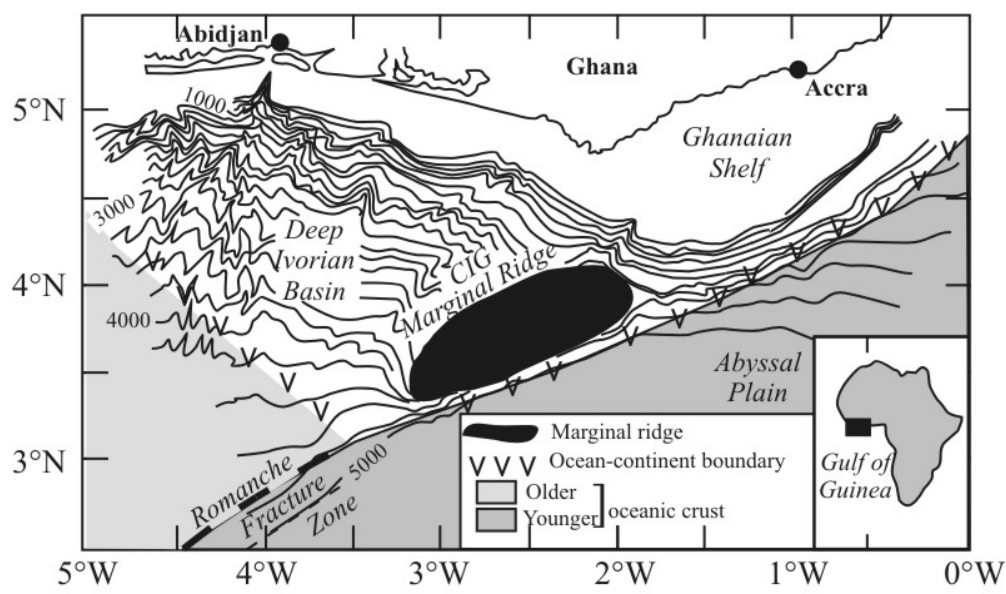

Figure 1

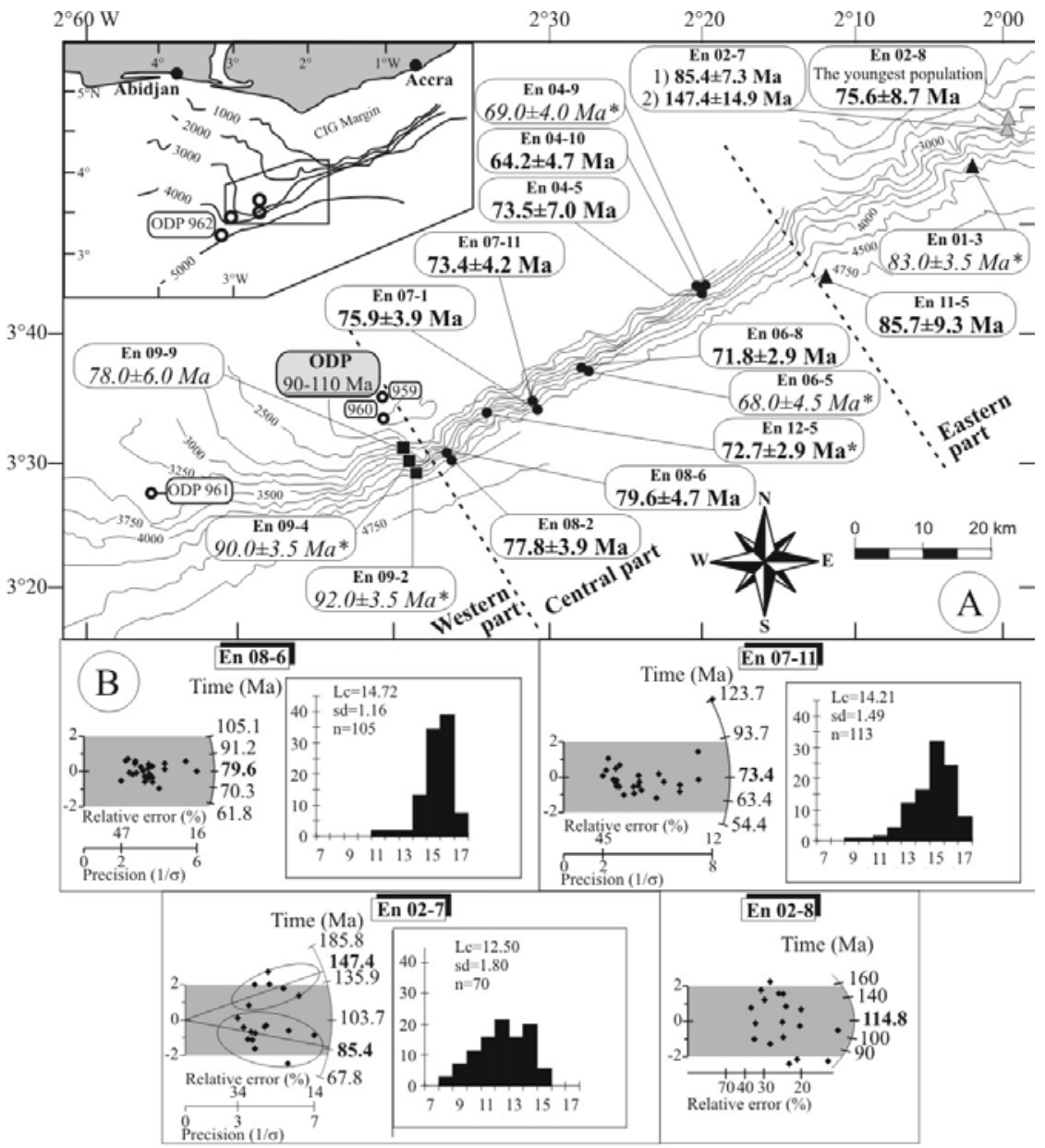

Figure 2 
Bigot-Cormier et al.

Figure 4
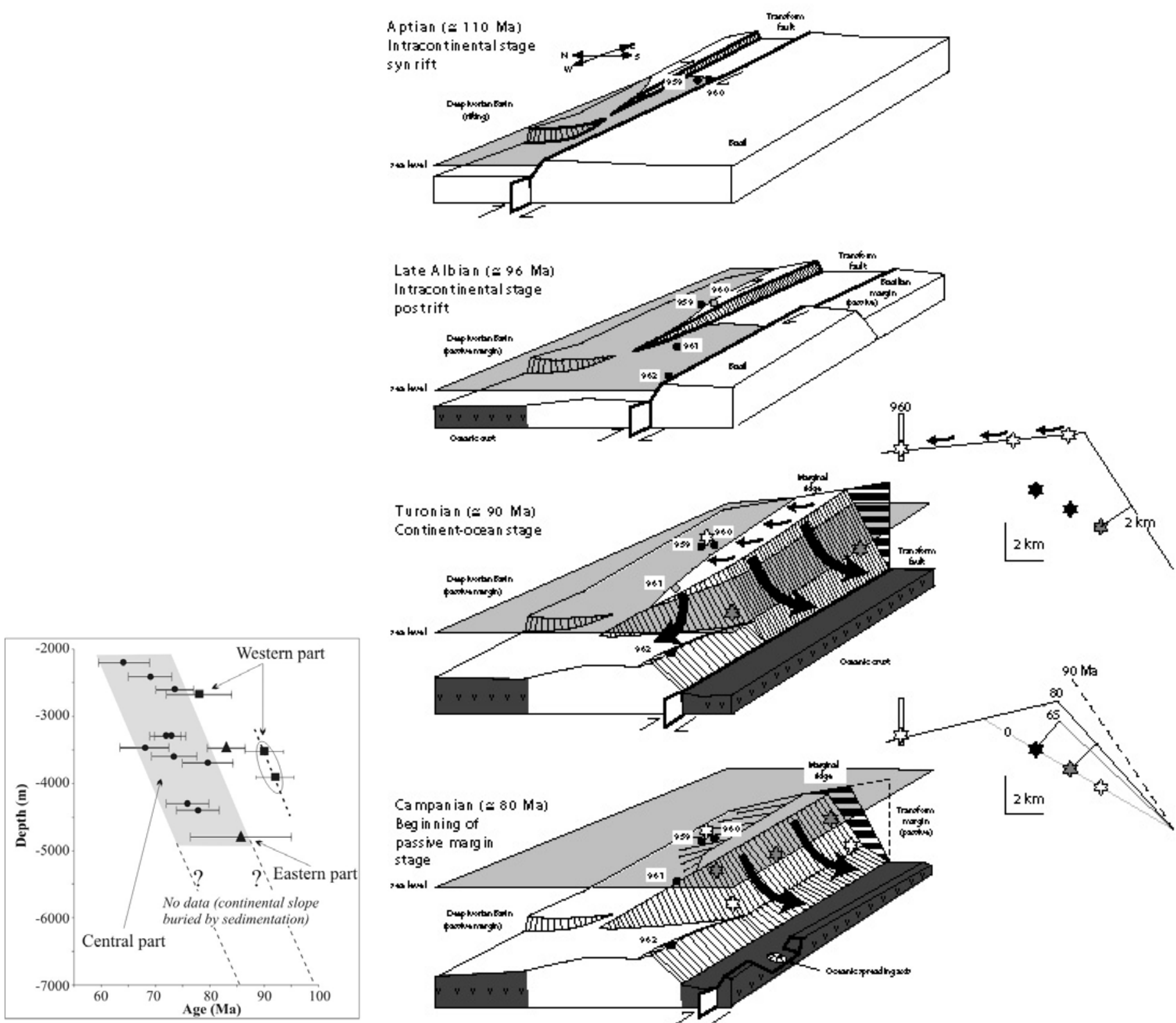

Figure?

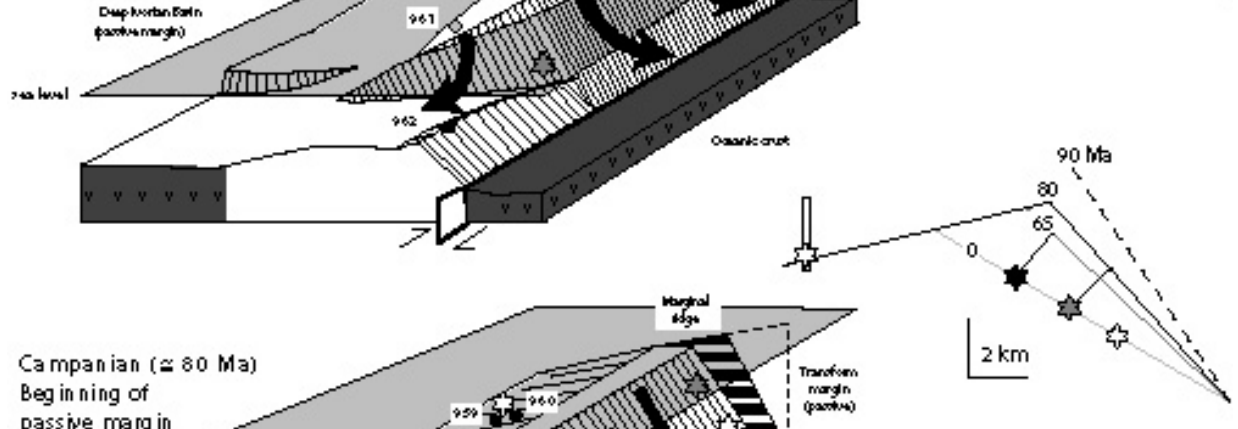

passive mang in

stage

$\rightarrow \infty$ lom

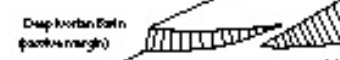
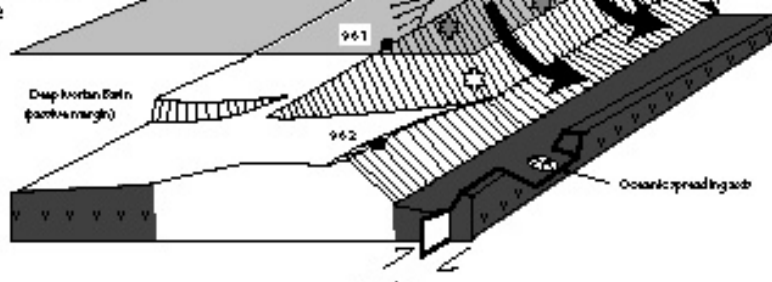

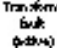

